ISSN 2410-1176 (Print) Вісник КНУКіМ. Серія Мистецтвознавство. Вип. 39. ISSN 2616-4183 (Online)

УДК 792.07:378.147.

\author{
Пацунов Валерій Петрович, \\ професор кафедри \\ режисури та акторської майстерності, \\ Київський національний \\ університет культури і мистецтв, \\ вул. С. Коновальия,36, Київ, Україна, 01133, \\ https://orcid.org/0000-0002-9757-3651 \\ v.patsunov@gmail.com
}

\title{
СЦЕНОГРАФІЧНІ ПЕРЕТВОРЕННЯ РОМАНУ Ф. ДОСТОСВСЬКОГО «ІДІОТ»
}

Мета дослідження. Розкриття алгоритму народження сценічного образу, висвітлення режисерського методу створення театральних метафор за допомогою сценографічних засобів виразності. Методологічною основою дослідження $є$ перетворення літературного тексту роману Ф. Достоєвського «Ідіот» у метафоричне видовище за допомогою сценографічних засобів виразності методами драматургічного аналізу літературного твору та режисерського синтезу мистецтв актора, композитора та сценографа на прикладі постановки вистави за вищезазначеним романом на сцені академічного театру ім. М. Садовського. Наукова новизна роботи полягає в розкритті авторської методики створення театральних метафор шляхом синтезу різних мистецтв на грунті власного режисерського та сценографічного досвіду. Висновки. Головним результатом дослідження є розкриття природи сценічних метафор, алгоритму їх народження та методики їх побудови. Формування метафоричного мислення нового покоління театральних режисерів дозволить вивести театральне мистецтво 3 «царства побутового реалізму» на широкий шлях образно-філософського осягнення дійсності, на рівень Театру Потрясіння.

Ключові слова: «Ддіот» Достоєвського; епічна форма; метафорична лексика; міраж.

Пацунов Валерий Петрович, профессор кафедры режиссуры и актерского искусства, Киевский национальний университет культуры и искусств, ул. Е. Коновальца,36, Киев, Украина

\section{Сценографические превращения романа Ф. Достоевского «Идиот»}

Цель исследования. Раскрытие алгоритма рождения сценического образа, освещение режиссерского метода создания театральных метафор с помощью сценографических средств выразительности. Методологической основой исследования является превращение литературного текста романа Ф. Достоевского «Идиот» в метафорическое зрелище с помощью сценографических средств выразительности методами драматургического анализа литературного произведения и режиссерского синтеза искусств актера, композитора и сценографа на примере постановки спектакля по вышеупомянутому роману на сцене академического театра им. Н. Садовского. Научная новизна работы заключается в раскрытии авторской методики создания театральных метафор путем синтеза различных искусств на почве собственного режиссерского и сценографического опыта. Выводы. Главным результатом исследования является раскрытие природы сценических метафор, алгоритма их рождения и методики их построения. Формирование метафорического мышления нового поколения театральных режиссеров позволит вывести театральное искусство с «царства бытового реализма» на широкую дорогу образно-философского постижения действительности, на уровень театра Потрясения.

Ключевые слова: «Идиот» Достоевского; эпическая форма; метафорическая лексика; мираж.

Patsunov Valerii, Professor of the Directing and Acting Skills Department, Kyiv National University of Culture and Arts, 36, Y. Konovaltsia St., Kyiv, Ukraine

The scenography transformations of F. Dostoevsky's novel «Idiot» 
The aim of the study is to disclose the creation algorithm of a scenic image, coverage of the director's method of creating theatrical metaphors with the help of scenography means of expressiveness. The methodological basis of the study is the transformation of F. Dostoevsky's novel «Idiot» literary text into a metaphorical spectacle with the help of scenography means of expressiveness through the dramatic analysis methods of the literary work and directorial synthesis of the actor skills, composer and scenographer on example of the aforementioned novel performance staged in Mykola Sadovskyi Vinnytsia State Academic Music and Drama Theater. The scientific novelty of the work is the reveal of the author's methodology for creating theatrical metaphors through the synthesis of various arts on the basis of his own directorial and scenography experience. Conclusions. The main result of the study is the disclosure of the stage metaphors' nature, algorithms for their creation and methods of constructing them. Formation of the metaphorical thinking of a new theatrical directors' generation will bring theatrical art from the «kingdom of everyday realism» to the broad path of figurative and philosophical comprehension of reality, to the level of the Shock Theatre.

Key words: F. Dostoyevsky novel «Idiot»; epic form; metaphorical language; mirage.

Вступ. Українська сцена значною мірою й донині перебуває в побутовонатуралістичних тенетах копіювальної естетики XIX ст., надто повільно рухаючись у бік образно-філософської, метафоричної лексики. Якщо головними інструментами образної мови театру є сценографія, музика та актор, то мистецтвом синтезу цих компонентів має володіти режисер, створюючи неповторну образну (метафоричну) мову сцени. Це відбувається завдяки використанню засобів сценографії, що ми й «побачимо» в цій статті.

Аналіз останніх досліджень та публікацій. У XXI ст. дослідження ролі сценографії в створенні театральних метафор не проводилися. Теоретичні праці другої пол. ХХ ст. «Искусство сценографии мирового театра» В. Березкіна, «Пластика сценического пространства» М. Френкеля, «Художник театра Даниил Лидер» Г. Коваленка та ін. публікації з питань розвитку сценографічного мистецтва хоча й висвітлювали роль сценографії у створенні театральних метафор, однак не розкривали алгоритму їх народження.

Мета дослідження полягає в розкритті алгоритму народження театральних метафор сценографічними засобами виразності на прикладі власної постановки вистави «Ддіот» Ф. Достоєвського (п’єса, режисура та сценографія В. Пацунова).

Виклад основного матеріалу. Велика сцена Вінницького академічного театру ім. М. Садовського, на якій в 1920 р. Гнатом Юрою, Амвросієм Бучмою та Семеном Семдором був започаткований Київський театр ім. І. Франка, мала цілком достатнє технічне та творче озброєння для реалізації досить амбітного режисерського задуму - вийти на рівень театру Потрясіння. Ставити чергову, навіть хорошу виставу вже давно для автора цієї статті не мало ніякого сенсу. Конче необхідно було вийти за межі власних можливостей. Для цього в розпорядженні режисера була досить міцна та цікава трупа, яка могла б конкурувати з багатьма київськими. Знайшлися в ній і Настасія Пилипівна, і Рогожин, i, головне, князь Мишкін!

Варто зазначити, що роман «Ддіот» Ф. Достоєвського є надто «незручним» для сценічного втілення. Тому й кожна його поява на сцені театру будь-якого статусу й рівня подія архі-надвичайна. Структура роману крихка, непослідовна, з безліччю відхилень від заявленого письменником курсу, нескінченних блукань у хащах необов'язкових сюжетних пухлин, яких вистачило б на кілька окремих романів - все це дало підстави провідним європейським літературознавцям піддати сумніву літературний хист Достоєвського, однак, залишивши за ним почесне місце у Всесвітньому Пантеоні Геніїв.

Отже, першим кроком режисера мало стати перетворення всесвітньо відомого роману в п’єсу. Наскільки є вільним режисер у процесі втручання в текст класика? Звернімося до автора. У листі Достоєвського до княгині Оболенської знаходимо: «С якась таємниия мистецтва, згідно з якою епічна форма ніколи не знайде собі відповідності в драматичній. Я навіть вірю, щуо для різних форм мистецтвв існують і відповідні їм ряди поетичних думок, 
ISSN 2410-1176 (Print) Вісник КНУКіМ. Серія Мистецтвознавство. Вип. 39. ISSN 2616-4183 (Online)

так щцо одна думка не може ніколи бути виражена в іншій, не відповідній їи формі. Інша справа, якщо Ви якомога більще переробите та зміните роман, при изьму залишите від нього лише один який-небудьь епізод, щуоб переопращювати в драму, або, беручи за основу початкову думку, зовсім зміните сюжет...» (1986, с. 225).

Як бачимо, класик надав нам велику свободу дій, визнаючи за режисером абсолютне авторське право на виставу. Виокремимо 3 його роману одну-єдину лінію - занурення ідеального героя в гущу людських взаємин, власне, зіткнення святого з грішним, а, головне, - катастрофічні наслідки цього зіткнення. Все інше - відсікаємо! Тобто, отримавши індульгенцію від Достоєвського, діємо за рецептом Мікеладжело.

Як відомо, в образі князя Мишкіна автор уявляв образ Христа. Однак цей задум втілити йому не вдалося - святий образ розчинився в сімейно-побутових чварах земного міщанського болота. Однак, не поспішаймо впадати у відчай - образна мова театру метафоричної лексики за сприяння мистецтва сценографії дає нам унікальну можливість не лише наблизитися до втілення первісного авторського задуму (Мишкін-Христос), але й подати у метафоричній (поетичній) мові прозаїчний текст роману. Адже, метафорична лексика всесильна. Вона здатна «врятувати» будь-якого генія, здатна будь-який факт життя, будь-яку безневинну земну подію здійняти до Всесвіту, будь-яку прозаїчну мову подати у поетичній мові. Як запевняв класик режисури Вс. Мейєрхольд, поставити на сцені можна навіть телефонну книгу. А таке під силу лише режисеру метафоричного віросповідання. « $У$ иъьму випадку, - як зазначав В. Белінський, - його нива безмежна, йому відкрито весь дійсний та уявний світ, все розкішне иарство вимислу. (...) ...і небо, і пекло! (...) ...в иьому витворі немає істини життя, але є істина почуттів; немає дійсності, (...) але є безодня поезії...» (1958, с. 56-57).

Саме зі Всесвіту з'являється наш Мишкін. У цьому нам допоміг великий екран, який протягом вистави відтворював міражі паралельної дійсності. (Не випадково вистава отримає назву «ІДІОТ. Міражі з антрактом»).

На екрані - відео-кадри живого Всесвіту. Під звуки ангельського хору з-поміж планет 3'являється князь Мишкін і в ритмі хорових тактів повільно рухається сходами донизу, опиняючись врешті-решт у затишних генеральських апартаментах сім'ї Спанчиних.

I Мишкін, і його оточення перебувають у паралельних світах, які не перетинаються. А якщо контакти між ними і трапляються (планети сходять з орбіт), то це призводить до катастрофи. Мишкін зустрів планету Земля в жалюгідному стані. На ній царює брехня, лицемірство, маніакальна жадоба грошей, пограбування та вбивства. Не лікує навіть гільйотина.

Режисерська оптика спотворює реалістичний стиль Достоєвського, іронізує над його персонажами. Потворність проглядається в усьому - жіноцтво сімейки Спанчиних одягнене в пташине пір'я, генеральські доньки пересуваються пластикою маленьких лебедів під музику Чайковського, мольбертом для своєї картини Аделаїда обирає... обличчя «ідіота» князя Мишкіна. Адже, з ідіотами дозволено робити все, що заманеться. Та й ідіоткам дозволено теж усе. Отака вимальовується дзеркальна ситуація в театрі кривих дзеркал.

У Достоєвського Мишкін діагностує персонажів. Про Настасію Пилипівну він скаже: «Дивне обличчя! Вона, мабуть, страшенно страждала. Про иче очі говорять. Ось иі дві краплинки під очима» $(1989$, с. 38$)$. У нашій виставі князь не лише діагностує, але й своїм екстрасенсорним випроміненням фізично впливає на партнерів, гармонізуючи їх душевний стан, зароджуючи в них процес цілющих перетворень. Так, під магічним впливом його поглядів та жестів генеральські доньки «оживають» та «розквітають». Це «диво» досягається засобами особливої пластики, містичної музики та, звичайно ж, випроміненням самого актора.

Про феномен людського випромінення натякав Костянтин Станіславський: «Не замечали ли вы в жизни или на сцене, при ваших взаимных общеения, ощущчения исходящего от вас волевого тока, который как бы струится через глаза, через конџы пальцев, через поры тела? Как назвать этот невидимьй путь и средство взаимного общения? Лучеиспусканием и лучевосприятием? Излучением и влучением? ...Близко время, когда 
невидимые токи, которые нас теперь интересуют, будут изучены наукой, и тогда для них создадут более подходящую терминологию» (1959, с. 267).

Однак цією унікальною властивістю людської природи Станіславський не скористався. Натяк залишився натяком. У будь-якому разі, чимала теоретична спадщина режисера не має жодних свідчень практичного володіння ним цією могутньою зброєю. Та й актори MXАТ в своїх мемуарах не залишили свідчень про факти випромінювання. Тодішня наука ще не мала достатнього матеріалу для цього. Та й сам режисер був надто зосереджений на іншому - на реалістичному відтворенні дійсності.

Принагідно зазначу, що ефект випромінення є невід'ємним могутнім засобом впливу театру Потрясіння, здатного занурювати глядача в стан глибокого трансу. Цей стан межує 3 гіпнозом, однак не є ним. Не важко здогадатися, що цією технікою на інтуїтивному рівні володіли актори давньо-грецького театру, без чого зіграти античну трагедію було б неможливо.

Станіславський залишив нам лише концепцію театру Переживання, а от для розробки концепцій театру Потрясіння йому не вистачило часу. Сучасна режисерська техніка концентрування енергетичних потоків акторів та генерування могутнього сумарного енергетичного поля, що, власне, і $є$ полем випромінення, стане предметом майбутньої статті автора. Розвиток сучасної науки дозволяє нам у XXI ст. оволодіти цією унікальною технікою впливу на глядача, творити театр найвищого естетичного, енергетичного та філософського рівня, яким $є$ Театр Потрясіння.

Та повернімось до вистави «діот». Хода нашого Мишкіна позбавлена будь-яких побутових ознак, а в окремих випадках вона перетворюється в гіпер-рапід, що посилює напругу випромінення, завдяки чому народжується дивне відчуття безтілесності героя, створюється ілюзія його Вознесіння. Якщо Станіславський теоретично ставив за мету відтворення «життя людського Духу», а на практиці все у нього зводилося лиш до «життя людини», тобто, до органічного відтворення реального життя реальною людиною, то наш Мишкін і є саме втіленням «життя людського Духу». Він став Духом, поряд з яким всі інші персонажі виглядають надто плотськими, гротесковими, подекуди шаржованими, навіть потворним, a, отже, - ідіотськими. Єдиною розумною істотою серед ідіотів виявився саме Мишкін.

Як бачимо, театральна метафорика народжується поза текстом. Вона здатна творити свій власний текст, незрівнянно багатший та глибший за текст літературний. Вона і $є$ Поезією театру. Аби таке стало можливим, конче необхідно позбавитися залежності від тексту п’єси. Як волав Лесь Курбас, «...Література заволоділа театром $і$ вбила $i$ театр $i$ його акторів» (1991, с. 41). Принагідно згадаємо й Антонена Арто: «Театр, де все...nідпорядковано тексту, це театр дурня, божевільного, збочения, торговия, антипоета...» (1993, с. 42). 3 того часу пройшло багато десятиліть, змінилося кілька поколінь, однак, як не дивно, і донині ці тези залишаються актуальними. Вони позначають величезну проблему театрального мистецтва, проблему режисури, проблему акторської майстерності, проблему театральної освіти. Сходіть у театр, шановні, і ви побачите, що переважну більшість вистав актори грають словами. На сцені процвітає балаканина. А слова ж брешуть. Словам вірить або дитина, або дурень. А от метафора не бреше, бо вона виявляє сутність характеру, образу, явища чи події. Це блискуче довели режисери Е. Крег, М. Рейнхардт, Вс. Мейєрхольд, С. Вахтангов, О. Таїров, О. Курбас, Ю. Любимов, П. Брук, Й. Штайн, Є. Гротовський, Р. Стуруа, Р. Віктюк, Е. Някрошюс, А. Жолдак... (далі кожний 3 вас, шановні, на власний смак може продовжити цей перелік).

У чому ж причина цього застійного явища? По-перше, радянська система винищила тих, хто наважувався відійти від побутового (соціалістичного) реалізму та творити образну лексику в мистецтві. Цей «геноцид» метафорики загальмував розвиток усіх мистецтв, зокрема, театрального, на століття. Винищена ціла школа образного мистецтва. Аби відродити iї, потрібно пройти шлях у кілька поколінь.

Автору цих рядків пощастило все своє творче життя присвятити побудові метафоричного театру «Золоті ворота», вдалось створити та впровадити в практику 
авторську програму єдиної в світі навчальної дисципліни «Експериментальна режисура», в назві якої зашифровано саме метафорику театру. Понад десять років вона ефективно діє в Національному університеті культури і мистецтв. Завдяки їй майбутні режисери формують образно-пластичне мислення, а вийшовши в театральний простір, успішно перетворюють сучасний побутовий театр в образний, завдяки чому отримують перемоги на різноманітних театральних фестивалях. Однак, це лише вузенька стежина, яка має надати українському театру широку дорогу образно-філософської лексики.

А вона твориться на уламках літератури. Режисер-метафорист «витрушує» 3 літератури всю iï душу і, відкинувши текст, як відпрацьовану ступінь космічної ракети, злітає у Всесвіт Образного Театру. Сподіваюся, переконливим прикладом подолання тексту навіть такого автора як Ф. Достоєвський, може слугувати фінал нашої вистави.

Пройшовши всі кола пекла, смерть Настасії Пилипівни, Мишкін божеволіє. Як зіграти божевілля? Історія театру багата акторськими штампами для передачі такого стану! Тому більшість сценічних божевільних схожі між собою. Якщо зібрати картотеку театральних божевільних, або, скажімо, змонтувати з них відео-нарізку, то отримаємо розкішне дебілшоу 3 досить обмеженим «репертуаром». Сценічний штамп тоді оволодіває актором, коли режисером не винайдено прийом, який би був переконливим засобом вияву цього своєрідного стану. У нашому випадку щасливою знахідкою виявилася звичайнісінька муха, про яку генерал Спанчин згадав на святкуванні дня народження Настасії Пилипівни в розповіді про те, як він вилаяв мертву стару, не підозрюючи про ії стан. Ось фрагмент цього монологу: "Але дивлюся, сидить бабуля якось дивно, обличчя на мене виставила, очі витріщила і ні слова у відповідь. Тиша, лише муха дзижчить» (1989, с. 154). Є в романі ще одна цікава згадка про муху князя Мишкіна: «Навіть иця крихітна мушка, яка дзижчить біля мене в сонячному промені, ...знає своє місие, любить його і щаслива. Тільки я нічого не знаю, нічого не розумію» $(1989$, с. 425-426).

А тепер повернімось, шановні, до фіналу вистави. Біля тіла Настасії Пилипівни Рогожин розповідає князю подробиці вбивства. I цілком логічним було б з'явитись мусі над трупом Настасії Пилипівни. I ми ії «з'являємо». Напрочуд настирливу! Вона вперто заважає Рогожину вести душевну розмову з князем. Він іiі відганяє, а вона, нахаба, кружляє над його головою, цілить то в лоба, то у вухо. Рогожину ніяк не вдається іiі здолати. Мишкін цікавиться: «Чим ти ї̈? Ножем? Тим самим?»

Рогожин: (Люто припечатав, нарешті, муху до коліна) «Тим самим!» Отакий він, наш Рогожин! Бездушний вбивця!

Згодом, коли Рогожин у хворобливому маренні та 3 диким галасом кинеться зачиняти двері від уявної поліції та зникне назавжди в темряві, Мишкін залишиться на самоті з тілом Настасії Пилипівни. I раптом мертву тишу порушить ніжне дзижчання нової крихітної гості. Вона прилетить до князя, який з радістю зустріне ії - єдину живу істоту серед мерців! (Виникає співставлення 3 протилежною реакцією Рогожина на муху). Мишкін підставляє їй свою дружню долоню. I мушка сідає на неї! Це викликає у князя дику радість. Він звертається до неї її мовою - комашиним дзижчанням. I, о, диво, мушка відповідає йому жалібним скигленням! Мишкін миттєво перетворюється на малу дитину, яка починає грайливо сміятися. Він знову надсилає подрузі сигнал любові, і та весело відлунює сигнал другові. Ця ідилія, що зненацька народилася біля неживого тіла Настасії Пилипівни, завершується зворушливим прощанням Мишкіна з Мушкою. Відчуваєте, любі, спорідненість їхніх імен - Мишкін та Мушка? Нарешті, Мишкін великодушно випускає Мушку на волю, немов птаха. Вона дзвінко відповідає йому вдячною фіоритурою за подаровану свободу та віддаляється вдалечінь.

Ця щаслива метафорична знахідка подарувала виставі не лише вражаючий виражальний засіб гри в божевілля, але й збагатила образ героя глибоким гуманістичним християнським світосприйняттям.

I от щасливий Мишкін (а всі божевільні, як відомо, неодмінно щасливі) кладе на свою спину тіло Настасії Пилипівни, руки якої розкинуті хрестом, і повільно, в гіпер-рапіді під 
звуки пісні «Голгофа» тягне свій хрест, прямуючи сходами вгору назустріч розіп'ятому Ісусу, що у версії Сальвадора Далі летить над Землею.

Чи потрібні тут слова? «Говорить і показує» Ії̈ Величність Метафора, що є перлиною Мистецтва, вибухом Пізнання, проникненням у Суть явища, трансплантацією в Дух людини.

I публіка, і мас-медіа одностайно зарахували вінницьку виставу «Ідіот» до мистецтва театру Потрясіння. I вирішальною зброєю в битві за творчу перемогу були головні герої цього опусу: Метафора та Випромінення, створені сценографією, музикою та актором під орудою режисера та сценографа.

Наукова новизна роботи полягає в розкритті авторської методики створення театральних метафор шляхом синтезу різних мистецтв на грунті власного режисерського та сценографічного досвіду.

Висновки. Використовуючи сценографію, режисер образного віросповідання може творити дива. Запліднена біо-енергією ії творців, вона відкриває шлях до Потрясіння, а через нього - і до Катарсису, що є найвищою формою взаємодії театру з публікою.

\section{Список використаних джерел}

1. Арто А. Театр и его двойник. Москва : Мартис, 1993. 192 с.

2. Белинский В. Г. О русской повести и повестях г. Гоголя. Москва : Гослитиздат, $1958.110 \mathrm{c}$.

3. Достоевский Ф. М. Собр. соч. В 30 т. Т. 29. Кн.1. Москва : Наука, 1986. - 565 с.

4. Достоевский Ф. М. Собр. соч. В 15 т. Т. 6. Ленинград : Наука, 1989. 672 с.

5. Молодий театр : генеза, завдання, шляхи / Упоряд. М. Г. Лабінський. Київ : Мистецтво, 1991. 316 с.

6. Станиславский К. С. Собр. соч. В 8 т. Т. 6. Москва : Искусство, 1959. - 466 с.

\section{References}

1. Arto, A. (1993). Teatr i ego dvoinik [Theater and its double]. Translated from French by V. Maksimov. Moskva: Martis.

2. Belinskiy, V.G. (1958). O russkoi povesti i povestyakh g. Gogolya [About the Russian story and stories of Mr. Gogol]. Moskva: Goslitizdat.

3. Dostoevskiy, F.M. (1986). Sobranie sochinenii. v 30 t. T. 29. Kn.1. [Collected Works. In 30 vols. Vol. 29. Book. 1.]. Moskva: Nauka.

4. Dostoevskiy, F.M. (1989). Sobranie sochinenii. v 15 t. T. 6. [Collected Works. In 15 vols. Vol. 6.]. Leningrad: Nauka.

5. Labinsky, M.G. (1991). Molodyi teatr : heneza, zavdannia, shliakhy [The Young Theater: Genesis, Problems, Paths]. Kyiv: Art.

6. Stanislavskiy, K.S. (1959). Sobranie sochinenii $v 8$ t. T. 6. [Collected Works. In 8 vols. Vol. 6.]. Moskva: Iskusstvo.

(C) Паиунов В. П., 2018

Стаття надійшла до редакиії: 31.06.2018 